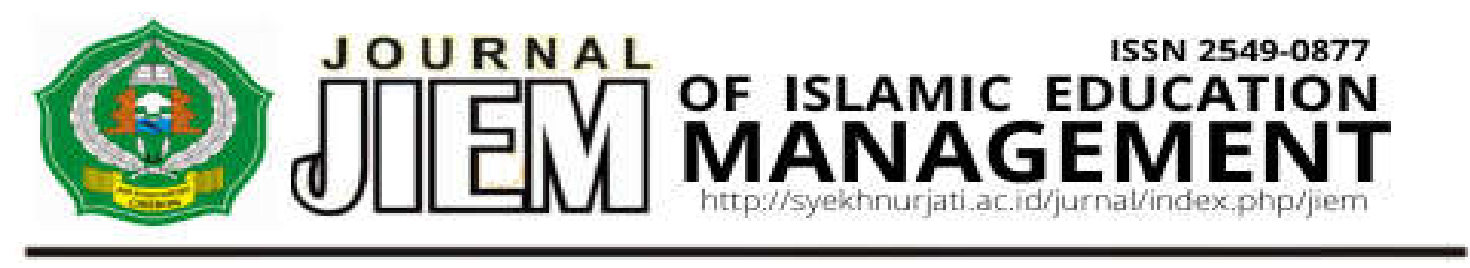

\title{
MANAJEMEN MUTU PENDIDIKAN UNTUK MENANGGULANGI "TAWURAN" PELAJAR MELALUI MODEL LEMBAGA PENDIDIKAN ISLAM
}

\author{
Subur \\ Institut Agama Islam Negeri (IAIN) Syekh Nurjati Cirebon \\ subur@syekhnurjati.ac.id
}

\begin{abstract}
Abstaks
Penulis mengamati dan mengikuti pemberitaan baik dari media cetak maupun media elektronika (TV) mereka yang melakukan "tawuran" kasusnya adalah berasal dari sekolahsekolah umum dan perguruan tinggi umum. Belum melihat maupun mendengar bahwa mereka yang melakukan "tawuran" dari siswa-siswa sekolah elite, madrasah atau Pondok Pesantren. Dari fonomena tersebut diatas memunculkan berbagai spekulasi dan solusi untuk mengatasi atas kejadian itu dengan mencoba berbagai alternative pemecahan diantaranya membuka atau merubah sekolah "biasa" menjadi sekolah elite, modern atau Boarding School Manajemen mutu pendidikan dalam artikel ini merupakan sebuah kajian kritis mengenai bagaiman sebuah pendidikan persekolahan harus dikelola secara efektif, efisien, berkeadilan untuk mewujudkan sebagaimana yang diharapkan, tidak melahirkan anak-anak yang tidak bermoral dan mereka menjadi "preman" jalanan yang gemar sekali melakukan "tawuran"
\end{abstract}

Kata Kunci : Manajemen Mutu Pendidikan, Tawuran Pelajar dan Lembaga Pendidikan Islam.

\section{A. Pendahuluan}

Pendidikan di Indonesia dalam pengertian sempit adalah penyelenggaraan pendidikan melalui lembaga baik dibawah Kementrian Pendidikan dan Kebudayaan Nasional, Kementrian Agama maupun dibawah Kementrian lainnya. Namun pada akhir-akhir ini justru ada beberapa kasus bahwa peserta didiknya mestinya mereka mempunyai karakter atau watak yang santun dan cinta damai, justru sebaliknya mereka sangat beringas dan mudah emosi, contoh kasus mereka melakukan "tawuran". Bahkan pada kasus lain mereka setelah mendapat kelulusan, melakukan konvoy naik sepeda motor mengganggu pengguna jalan lainnya dan corat-coret baju yang semestinya tidak pantas dilakukan oleh mereka yang sering dinamakan kaum "terpelajar". Lebi ironis lagi di sejumlah kasus "tawuran" itu dilakukan oleh mahasiswa.

Era modern menjadi era yang diimpikan masyarakat, karena modern identik dengan kemajuan. Namun sayangnya tolak ukur kemajuan ini biasanya adalah kemajuan dibidang sains dan teknologi bukan akhlak al-karimah. Masyarakat modern adalah masyarakat yang menghargai sains dan teknologi, pendidikan modern adalah pendidikan yang penuh dengan infrastruktur dan aktifitas berbasis sains dan teknologi.

Ketika sains dan teknologi menjadi "tuhan" baru, maka seluruh energi 
masyarakat tersedot untuk menggapai tujuan tersebut, termasuk di bidang pendidikan. Kebijakan pendidikan telah digiring kearah itu. Kemunculan berbagai nomenklatur institusi pendidikan seperti sekolah elite, madrasah model, madrasah unggulan, madrasah terpadu, RSBI, SSN dan lain sebagainya adalah bagian dari responsibilitas lembaga pendidikan baik dibawah Kementrian Pendidikan dan Kebudayaan Nasional maupun Kementrian Agama RI atas "tuhan" sains dan teknologi itu(Anis Masykur,2010:6)

Madrasah model atau bahkan sekolah modern Islam yang sangat khas dapat juga dikatakan sekolah elite karena sejumlah alasan yaitu bahwa madrah itu bersifat elite dari sudut akademis, dalam beberapa kasus, hanya siswa-siswi terbaik yang dapat diterima oleh madrasah itu. Gurunya juga telah diseleksi secara kompetitif. Madrasah itu juga memiliki berbagai sarana pendidikan yang jauh lebih baik dan lengkap. Semua itu membuat siswanya jauh lebih baik secara akademis. Tidak diragukan lagi bahwa kisah sukses madrasah-madrasah elite tersebuat mendorong Kemendikbudnas dan Kementrian Agama RI untuk terus mengembangkan sekolah elit atau madrasah-madrasah Model.

Fenomena siswa atau mahasiswa yang sering melakukan "tawuran" atau perbuatan yang kurang baik muncul dewasa ini bersumber dari akhlak. Akhlak yang baik adalah semulia-mulianya sesuatu. Dengan akhlak yang baik, manusia menjadi lebih tinggi derajatnya ketimbang derajat binatang. Andai saja akhlak manusia itu lenyap dari dirinya, maka tidak ada lagi perbedaan antara manusia dan binatang, secara sederhana perbedaan keduanya hanya terletak bahwa manusia bisa berbicara, sementara binatang tidak, dan para filosof berpendapat bahwa karena akal dan akhlak baiklah manusia berbeda dengan binatang (Ibnu Miskawaih, 1985:15).

Kualitas baik pendidikan suatu bangsa, semakin baik pula kualitas bangsa itu, semakin baik akhlak peserta didik adalah suatu cerminan sebuah keberhasilan pendidikan, itulah asumsi secara umum terhadap program pendidikan suatu bangsa. Secara faktual pendidikan menggambarkan aktivitas sekelompok orang seperti siswa, guru, dan tenaga kependidikan lainnya. Kemudian secara perspektif yaitu memberikan petunjuk bahwa pendidikan adalah muatan, arahan, pilihan yang ditetapkan sebagai wahana pengembangan masa depan peserta didik yang tidak terlepas dari keharusan control manusia sebagai pendidik.

Pendidikan tidak hanya dilihat dari pengertian yang sempit yaitu sebagai kegiatan belajar mengajar di kelas saja dan suatu usaha membantu orang lain menjadi "pintar". Secara prinsip bahwa pendidikan itu dapat memberikan konsep yang lebih luas dan lintas cultural atau "Cross Culture". Disamping itu pendidikan sebaiknya mengandung pengertian yang lebih luas dari pengajaran, karena sasaran pendidikan tidak hanya mencakup pengembangan intelektualitas saja akan tetapi lebih ditekankan pada proses pembinaan kepribadian atau akhlak alkarimah peserta didik secara menyeluruh.

\section{B. Pembahasan}

1. Definisi Mutu dan Manajemen Mutu Pengertian mutu memiliki variasi pengertian sebagaimana didefinisikan oleh masing-masing orang atau pihak. Produsen atau penyedia barang dan jasaakan berbeda dalam mendefinisikan mutu dengan konsumen atau pengguna barang/ jasa itu. Satu kata yang hamper sama dalam konsep mutu ditijau dari pihak prodesen maupun konsumen adalah "kepuasan". Yaitu barang atau jasa yang dikatan mutu jika dapat memberikan kepuasaa baik bagi pelanggan maupun produsennya.

Manajemen mutu merupakan sebuah konsep yang mengaplikasikan berbagai prinsip mutu untuk menjamin suatu produk barang atau jasa memiliki spesifikasi mutu yang ditapkan secara menyeluruh dan berkelanjutan, artinya mulai dari input, proses, oautpu dan outcome. Dalam dunia pendidikan, layanan purna terkait dengan keterlibatan alumni dalam pengelolaan dan pengembangan sekolah. Semua sistem organisasi diposisikan sebagai bagian untuk menjamin mutu dan disinergikan melalui kepemimpinan

2. Sifat Agresif dan Krisis Akhlak AlKarimah Kaum Terpelajar.

a. Definisi Sifat Agresif.

Secara kejiwaan semua manusia mempunyai sifat agresif. Agresif berasal dari kata agresi atau 
aggression berarti penyerangan atau serangan, Secara psikologi artinya perasaan marah atau tindakan kasar akibat kekecewaan atau perbuatan bermusuhan dan bersifat penyerangan pisik ataupun psikis. Sedangkan agresif adalah kecenderungan atau keinginan menyerang orang lain yang menghalangi tercapainya suatu tujuan (Suharso dan Ana Retnoningsih, 2005:20).

Agresi ialah segala perbuatan yang dimaksudkan sebagai serangan terhadap orang lain dan juga menimbulkan sifat permusuhan. Dalam kehidupan sehari-hari banyak sekali terdapat contoh agresi yang terdapat di antara manusia, contoh kasus terjadi pada kaum terpelajar baik itu pada tingkat menengah maupun mahasiswa, bahkan kerap kali kita melihat atau mendengar mereka dianiyaya, disiksa, disakiti atau bahkan dibunuh.

Dalam batin kita tersembunyi kekuatan-kekuatan yang mendorong kita kearah perbuatan jelek, sedangkan kita sendiri tidak sadar akan kekuatankekuatan itu. Bila hasrat batin itu demikian kuat, tetapi terhalang oleh keadaan dari dunia luar, maka timbullah reaksi menyerang terhadap penghalang itu, timbullah agresi. Jadi agresi itu terutama terjadi bila seseorang, dalam mencapai tujuannya dihalanghalangi oleh orang lain. Disamping itu sebab lain agresi antara lain; iri hati, kebebasan yang dibatasi, perintah yang menjengkelkan, tersinggung perasaan dan kehormatan, dihina, dan lainlainnya, hal ini menjadikan mereka marah.

Marah sebenarnya merupakan gejolak jiwa, yang mengakibatkan darah dalam hati mendidih dan nafsu membalas, seluruh urat syaraf dan otak tergelapi oleh asap pekat yang merusak keadaan hati. Dalam keadaan ini seseorang dilukiskan seperti gua yang penuh dengan api. Jilatan dan asap api yang berkobar di dalamnya sangat menyesakkan. Karenanya, kobaran-kobaran dan desisan-desisan yang biasa kita sebut suara api ini semakin dahsyat, dan dengan begitu sulit dipadamkan. Upaya apapun untuk memadamkannya bukan saja siasia, tetapi juga malah memperhebat kobaran api. Itulah sebabnya mereka menutup mata dan telinga terhadap saran dan nasihat, dan bahkan segala bentuk anjuran justru semakin memperbesar amarah dan mereka tidak berpikir panjang.

Socrates berkata "Saya lebih berharap pada kapal yang diserang badai angin dan ombak dahsyat, dibanding menghadapi orang yang sedang marah. Sebab, kapal yang diterjang badai dan ombak, awak kapal bisa mengatasi dengan berbagai cara dan alat. Tapi jiwa yang sedang marah tidak dapat diselamatkan oleh alat dan cara apa pun. Sebab, upaya untuk meredakan amarah, entah dengan memohon, nasihat, atau dengan sikap menunduk, malah seperti tumpukan kayu kering diatas api, yang justru menambah kobaran api tersebut" (Ibnu Miskawaih, 1985 :174).

b. Krisis Akhlak Al-Karimah

Banyak hal yang menjadi penyebab agresif dan marah seperti sombong, cekcok, meminta dengan paksa, bercanda, berolok-olok, mengejek, khianat, berbuat salah, dan sebagainya. Semua itu puncaknya adalah nafsu balas dendam atau "tawuran". Namun penyebab itu ada obatnya sehingga penyebab itu bisa sepenuhnya dapat diatasi bahkan ditiadakan dengan mendidik mereka mempunyai akhlakul al-karimah.

Krisis artinya keadaan yang genting atau gawat (Suharso dan Ana 2005:269).Akhlak bisa juga dinamakan karakter yaitu suatu keadaan jiwa, Al Karimah artinya mulia, atau cinta damai. Sehingga krisis akhlak al-karimah dapat diartikan keadaan jiwa bertindak tanpa dipikir atau dipertimbangkan secara mendalam. Keadaan ini ada 
dua jenis. Pertama, alamiah dan bertolak dari watak. Misalnya pada orang yang gampang sekali marah karena hal yang paling kecil. Kedua, tercipta melalui kebiasaan dan latihan atau pendidikan. Kaum Stoik, beranggapan bahwa manusia secara alami baik. Kalaupun jadi buruk, itu disebabkan pergaulannya dengan orang-orang buruk perilakunya(Ibnu Miskawaih, 1985 : 56).

Syariat agama merupakan faktor yang dapat meluruskan akhlak mereka sehingga mereka terbiasa melakukan perbutan yang baik, sekaligus mempersiapkan diri mereka menerima kearifan, kebajikan, dan penalaran yang akurat. Substansi manusia mempunyai aktivitas yang khas, yang tidak ada pada lainnya di dunia ini, sebab itu, pembinaan akhlak (karakter) bertujuan mencetak tingkah laku manusia yang baik, sehingga mereka berprilaku terpuji, sempurna sesuai dengan substansinya sebagai manusia dan mereka mempunyai akhlak al-karimah

c. Modernisasi Pendidikan Islam di Indonesia Gagasan program modernisme pendidikan Islam mempunyai akarnya dalam gagasan tentang "modernisme" pemikiran dan institusi Islam secara keseluruhan, sehingga kadangkadang antara pendidikan Islam dewasa ini tidak bisa dipisahkan dengan kebangkitan gagasan dan program modernisme Islam. Tetapi bagaimanakah sebenarnya pengertian modernisme. Modernisme berasal dari kata modern artinya terbaru atau mutahir. Modernisme artinya gerakan yang bertujuan menafsirkan kembali doktrin tradisional, sedangkan modernisasi artinya proses pergeseran sikap dan mentalitas sebagai warga masyarakat untuk bisa hidup sesuai dengan tuntutan masa kini (Suharso dan Ana Retnoningsih, 2005:225). Modernisasi pendidikan Islam di Indonesia lebih dikenal dengan istilah "pembangunan (develovment)". Gerakan reformis muslim yang mensporsori perubahan tersebut menemukan momentumnya pada abad ke-20 ini. Mereka berpendapat bahwa untuk merespon perkembangan pendidikan baru itu diperlukan perubahan sistem pendidikan Islam. Dalam konteks inilah dapat disaksikan munculnya dua bentuk lembaga pendidikan modern dalam Islam. Pertama, sekolah-sekolah umum model Belanda tetapi diberi muatan pengajaran Islam. Kedua, madrasah-madrasah modern yang secara terbatas mengadopsi substansi dan metodologi pendidikan modern Belanda.

Kemunculan modernisasi pendidikan Islam di Indonesia berkaitan erat dengan pertumbuhan gagasan modernisme Islam di kawasarn ini. Gagasan modernisme Islam yang menemukan momentumnya sejak abad 20 tersebut, pada lapangan pendidikan direalisasikan dengan pembentukan lembaga-lembaga pendidikan modern. Modernisme dan modernisasi sistem kelembagaan pendidikan Islam itu sebenarnya berlangsung di masa-masa mendatang. Tetapi modernisme sistem kelembagaan pendidikan Islam itu berlangsung bukan tanpa kritik dan problem. Bahkan dalam beberapa tahun terakhir ini kritik yang berkembang di tengah-tengah masyarakat Muslim, khususnya di kalangan pemikir dan pengelola pendidikan Islam itu sendiri kelihatannya semakin vocal.

Indonesia mempunyai sejumlah modal dasar yang memadai untuk mewujudkan cita-cita itu. Di antara modal dasar terpenting adalah kenyataan bahwa rakyat dan bangsa Indonesia adalah umat yang agamis dan sangat menghormati ajaran-ajaran agamanya. Ajaran-ajaran agama juga mencakup nilai-nilai moral dan etis pada gilirannya dapat diterjemahkan ke dalam pengembangan sains-teknologi yang berwawasan moral dan etis tadi. Bahkan dalam keberhasilan dan kemajuan pembangunan sekarang ini, kesadaran 
bangsa Indonesia tentang pentingnya agama semakin meningkat pula, sehingga membuat upaya kearah pengembangan sains-teknologi yang berwawasan moral dan etis menjadi semakin prospektif.

Peningkatan antusiasme keberagamaan itu pada gilirannya juga menimbulkan perkembanganperkembangan baru terhadap pendidikan Islam, sebagaimana akan kita lihat dibawah ini.

Tetapi dengan jujur harus kita akui, pendidikan pada umumnya dan pendidikan Islam pada khususnya hingga saat ini kelihatan sering terlambat merumuskan diri untuk meresponi "keluhan" dan kecenderungan perkembangan masyarakat. Sistem pendidikan kebanyakan masih lebih cenderung mengorentasikan diri pada bidang-bidang kognisi ketimbang mengorentasikan mereka menjadi berbudi luhur. Karena itu, sudah saatnya bagi kita untuk lebih serius menangani pembaharuan dan pengembangan sistem pendidikan pada umunya dan pendidikan Islam pada khususnya yang masih bersifat sepotongsepotong atau tidak komprehensif dan menyeluruh.

Jika kelemahan tersebut di atas tidak segera diatasi, maka sulit bagi kita untuk mengharapkan sistem dan lembaga pendidikan bisa benar-benar fungsional dalam ikhtiar penyiapan generasi yang berkualitas tinggi dan kompetitif untuk menjawab tantangan zaman. Pada hemat penulis, berbagai perubahan dan tawaran sebagaimana tersebut di atas harus segera dilakukan dalam sistem pendidikan.

\section{Alternatif /Solusi Mengatasi "tawuran" pelajar \\ 1. Melalui Pembelajaran diPondok Pesantren. \\ Pondok pesantren adalah salah satu} lembaga pendidikan yang sangat merakyat dan semua lapisan masyarakat kelas menengah kebawah dapat menikmati lembaga ini. Keberadaan pandok pesantren sudah ada sejak dulu sebelum Indonesia meredeka. Namun dalam perjalanannya mengalami pasang-surut.

Pengakuan terhadap keberadaan pesantren secara eksplisit baru terjadi pada tahun 2003, dengan disahkannya UndangUndang Nomor 20 tahun 2003 tentang Sistem Pendidikan Nasional. Undangundang yang disahkannya pada tanggal 8
Juli 2003 itu mengatur tentang penyelenggaraan pendidikan secara nasional. Salah satu poin penting dan juga menjadi titik perdebatan yang "alot" adalah diakomodirnya pendidikan agama dan pendidikan keagamaan. Meski sebutan pondok pesantren dalam peraturan tersebut tidak muncul secara explisit.

Ketika era reformasi dan era demokratisasi telah digulirkan bahkan menjadi "jargon", makin membuka ruang selebar-lebarnya bagi pondok pesantren untuk dapat mengembangkan eksistensinya. Puncaknya adalah ketika dikeluarkannya Peraturan Pemerintah nomor 55 tahun 2007 tentang Pendidikan Agama dan Keagamaan. Eksistensi pondok pesantren sebagai lembaga pendidikan keagamaan bukan saja harus memperoleh perhatian dari pemerintah, tetapi sudah mendapatkan kesetaraan dengan lembagalembaga pendidikan lainnya (Anis Masykur,2010:159)

Fasilitas pendidikan formal juga mendapat rekomendasi dari pemerintah RI. Yaitu pondok pesantren dapat menyelenggarakan pindidikan formal seperti MTs, MA, SMP, atau SMA, dan sebagainya. Pendidikan formal adalah jalur pendidikan yang terstruktur dan berjenjang. Pendidikan formal merupakan pendidikan yang umum diselenggarakan di sekolah-sekolah. Jalur pendidikan ini mempunyai jenjang pendidikan yang jelas.

Selama ini pondok pesantren dikelola atas prakarsa dan swadaya masyarakat. Namun dari sinilah pesantren mampu melahirkan tokoh-tokoh nasional dan internasional, dan mampu memberikan sumbangsihnya yang sangat berarti bagi kedamaian dan kehidupan keberagamaan di Indonesia. Sehingga sangat mungkin dengan perhatian yang besar dari pemerintah, pondok pesantren dapat meningkatkan kapasitasnya untuk menyelenggarakan pendidikan formal yang lebih berkualitas dan dapat menanamkan pada siswa-siswinya ber-akhlakul alkarimah.

Perubahan sistem nilai dengan memperluas peta kognitif peserta didik, maka pendidikan menanamkan nilai-nilai yang merupakan alternative bagi sistem nilai tradisional atau sistem yang selama ini berjalan. Perluasan wawasan ini akan merupakan pendorong bagi tumbuh dan berkembangnya semangat untuk 
berprestasi, dan mobilitas sosial serta dapat mengatasi persoalan pendidikan yaitu mengatasi "tawuran" pelajar.

\section{Pendidikan Model "Boarding School"} Muncul dan berkembangbiaknya "Boarding School" tampaknnya memiliki dampak yang berjangkauan laus terhadap masa depan masyarakat Muslim Indonesia. Sekolah-sekolah dan madrasah-madrasah yang menawarkan pendidikan berkualitas tersebut tidak hanya memberikan konstribusi pada perbaikan pendidikan Islam di Indonesia, melainkan juga pada proses pembentukan akhlak siswa sehingga mereka tidak melakukan "tawuran".

Model peng-asrama-an bagi para pelajar merupakan salah satu ciri menonjol pendidikan pesantren. Pola pesantren kemudian diadopsi oleh sekolah formal yang kemudian menerapkan model boarding school. Sistem pemondokan ini bisa menjadi media yang efektif untuk menghasilkan disamping output berkualitas, tetapi juga dapat membentuk mereka mampu mengendalikan dirinya, sebab muatan-muatan pendidikan keagamaan yang ditransformasikan kepada para siswanya tidak hanya menjadi tabungan pengetahuan, malahan lebih dalam lagi mereka dapat mengaktualisassikan nilai-nilai keagamaan dibawah pengawasan ustadz, maupun kyai. Proses santrinisasi penulis meminjam istilah santri yang berada pada pondok pesantren. Mereka dapat digambarkan melalui dua cara. Pertama, para siswa dari sekolah-sekolah umum disamping mereka mempelajari ilmu-ilmu umum, mereka juga mempelajari ilmuilmu Islam, mulai dari bagaimana membaca al-Qur'an, bagaimana melaksanakan salat dengan tepat dan benar, hingga ajaran-ajaran Islam yang mendasar. Proses penanaman ajaran dan praktik-praktik Islam tentu saja lebih intens bila dilakukan di sekolah-sekolah atau madrasah-madrasah yang memakai sistem asrama atau boarding school. Kedua, para siswa tersebut selanjutnya membawa Islam yang mereka telah pelajari dibawa ke rumah, bahkan mereka mengajarkan kepada orangtuanya. Dengan demikian sebuah pola baru yaitu "santrinisasi" muncul dikalangan keluarga.
Lebih jauh, para orangtua Muslim pada umumnya percaya bahwa lingkungan madrasah dan sekolah yang berada pada boarding school lebih aman dibandingkan dengan sekolah umum. Mereka yang bersekolah dilingkungan boarding school tidak pernah terlibat, misalnya, dalam tawuran antarsiswa dari sekolah yang berbeda sebagaimana umum kasus yang terjadi di sekolah-sekolah umum(Azyumardi Azra, 1999:81).

$$
\text { Sistem boarding school }
$$
menekankan moteda pengajaran yang orentasinya pada penguasaan substansi materi keilmuan (bukan target kurikulum). Juga di sekolah-sekolah boarding dikembangkan kurikulum sendiri yang dikonstruksi sesuai dengan konsep pendidikan yang memiliki dengan memasukan unsur-unsur kemampuan dasar yang diinginkan oleh kurikulum nasional.

Tenaga pengajar di sekolah-sekolah tersebut memiliki ruang kreativitas yang cukup luas, sehingga setiap inovasi dalam penyelenggaraan pembelajaran dapat dilaksanakan. Seperi halnya di pesantren, para siswa didorong untuk mampu belajar mandiri. Dengan demikian, upaya pencapaian target kualitas dalam pemahaman materi pengajaran bisa dilakukan sekolah yang bersangkutan sesuai dengan pendekatan yang dikembangkannya sendiri.

Demikian juga dilihat dari sistem pembinaan siswa, mengutamakan aspek pembentukan kepribadian (akhlak) dengan disiplin tinggi. Pembinaan siswa dilakunan secara intensif baik dalam maupun luar kelas. Untuk itu siswa di sekolah tersebut seluruhnya harus tinggal di asrama. Tujuannya adalah untuk menumbuhkan mentalitas kemandirian pada diri siswa.

\section{Madrasah Model}

Madrasah model adalah madrasah konvensional yang diterapi secara khusus untuk menjadi "model" madrasah yang berkualitas, sehingga dapat menjadi contoh madrasah negeri dan swasta disekitarnya dan dapat juga menggerakan dan meningkatkan kualitas madrasah lain di daerah sekitarnya.

Intervensi utama terhadap madrasah model khususnya Madrasah Aliyah (MA) adalah meningkatkan kualitas bidang studi matamatika, fisika, kimia, biologi, dan bahasa Inggris, disamping 
manajemen dan sarana-prasarana belajar(Husni Rahim, 2005:165)

Madrasah model diharapkan dapat menjadi "pemicu" dan penggerak percepatan kualitas madrasah terutama dalam bidang umum agar bisa mengimbangi sekolah umum. Untuk itu kepada madrasah model diberi fasilitas yang memadai untuk proses belajar mengajar dan bagi guru-gurunya mendapat kesempatan untuk meningkatkan kemampuannya baik melalui pelatihan dan penataran maupun melalui pendidikan lebih lanjut pada jenjang yang lebih tinggi.

\section{Madrasah Terpadu}

Konsep madrasah terpadu bukanlah konsep yang berdiri sendiri, tetapi merupakan konsep pendukung yang diintegrasikan dengan konsep madrasah model dan madrasah unggul. Dengan demikian akan terjadi sinergi yang kuat dalam mewujudkan madrasah berkualitas yang Islami. Yang diinginkan dari konsep madrasah terpadu adalah;

a. Mensinergikan berbagai potensi kekuatan madrasah (MIN, MTsN dan MAN) yang berada di satu lokasi untuk saling membantu dan mengisi kekuatan dan kelemahan masingmasing menjadi satu kekuatan yang mendorong dan mempercepat peningkatan kualitas madrasah yang Islami.

b. Melahirkan keterpaduan kualitas yang merata antara ketiga jenis pendidikan tersebut diatas, sehingga memiliki daya tarik yang sama kuatnya dari masyarakat peminat madrasah.

c. Memiliki manajemen terpadu yang mencakup struktur organisasi, arah pengembangan, pendanaan yang mendukung, dan lain-lain, (Husni Rahim, 2005:169)

Organisasi madrasah terpadu disusun atas dasar pertimbangan prinsip ekonomis, efektif, dan efisien, dan bukan justru berakibat mengurangi ruang gerak masing-masing jenjang madsarah yang ada. Yang diperlukan adalah koordinasi dari masing-masing madrasah, dan dilakukan secara fleksible, menguntungkan semua pihak, dan menyenangkan. Unitunit yang dibangun didasarkan atas kebutuhan nyata dengan alasan-alasan yang dapat dipertanggungjawabkan, baik dari sisi ekonominya maupun efektivitasnya.

\section{Sekolah Elite Muslim dan Full Day School}

Sekolah elite nuslim muncul sejak awal tahun 1990 an, sebagian dari sekolahsekolah itu mulai menyatakan dirinya secara formal dan diakui oleh banyak masyarakat sebagai "sekolah unggul". Sebab itu, sekolah-sekolah elite ini pada umumnya mahal dari segi pembiayaannya. Oleh sebab itu tidak semua orang tua Muslim mampu mengirimkan anaknya masuk pada sekolah-sekolah tersebut. Akibatnya siswa yang sekolah tersebut umumnya berasal dari keluarga kaya atau elite, sehingga sekolah itu disebut "sekolah elite".

Sekolah elite yang pertama kali berdiri adalah sekolah Islam Al-Azhar yang berlokasi di dalam komplek masjid Agung al-Azhar di Kebayoran Baru Jakarta Selatan. Kini sekolah Islam alAzhar memiliki cabang diberbadai daerah, seperti Cirebon, Surabaya, Sukabumi, Serang, Semarang dan sebagainya.

Kurikulum sekolah ini ditetapkan Depdiknas. Namun sebagaimana bisa diduga, sekolah ini memberikan penekanan khusus pada pengajaran mata pelajaran agama Islam. Karena sekolah al-Azhar tidak mengadopsi sistem asrama, seluruh proses pengajarannya dilakukan pada jamjam sekolah formal yang lebih panjang daripada jam belajar pada sekolah-sekolah lainnya. Model ini sering disebut "full day School".

Seiring dengan semakin meningkatnya populeritasnya sekolah alAzhar, berkembang pula sejumlah Sekolah Elite Muslim lainnya, tidak hanya di wilayah Jakarta, melainkan juga di beberapa provinsi lainnya di Indonesia.

\section{Kesimpulan}

Uraian di atas diharapkan mampu memberikan gambaran sederhana tentang solusi alternative mengatasi "tawuran" pelajar. Lembaga-lembaga pendidikan khususnya pendidikan Islam juga ditantang oleh pertumbuhan sains dan teknologi yang sangat pesat, sehingga sangat mempengaruhi perkembangan pendidikan di Indonesia.

Banyak pemikir menjelaskan bahwa krisis moral atau akhlak pelajar 
yang berkembang dewasa ini disebabkan oleh pengaruh setidak-tidaknya "modernisme". Mereka yakin bahwa agama memiliki otoritas atas manusia untuk menjadi manusia yang berakhlak. Lembaga-lembaga pendidikan sebagai salah satu pusat bagi kemajuan manusia harus mengambil peran dalam membangun akhlak atau moral tersebut demi kemanusiaan. Karena itu pendidikan harus mencakup pertumbuhan manusia dalam segala aspeknya; spiritual, intelektual, imajinatif, fisik, ilmiah dan sebaginya. Hal ini mendorong semua aspek ini kearah kebaikan dan untuk mencapai kesempurnaan.

Dalam kerangka perwujudan fungsi idialnya untuk peningkatan kualitas dan

\section{E. Daftar Pustaka}

Azra, Azyumardi. (1999), Pendidikan Islam, Tradisi dan Modernisasi Menuju Milenium Baru. -:Logos

Masykhur, Anis. (2010). Menakar Modernisasi Pendidikan Pesantren., Barnea: Pustaka.

Miskawaih, Ibnu. (1985).Tahdzib AlAkhlaq, Dar Al-Kutub Al-'Ilmiyah., Lebanon: Bairut.

Purwanto, Ngalim (1995).Ilmu Pendidikan Teoritis dan Praktis. Bandung:Remaja Rosdakarya.

Sagala, Syaeful.,(2000) Administrasi Pendidikan Kontemporer. Bandung:Alfabeta.

Suharso, dkk (2005.).Kamus Besar Bahasa Indonesia. Semarang:Widya Karya. mengatasi " tawuran" pelajar , sistem pendidikan yang ada sekarang ini secara berangsur-angsur harus berani menjawab kebutuhan dan tantangan yang muncul dalam masyarakat kita sebagai konsekuensi logis dari perubahan. Perubahan-perubahan itu misalnya lembaga pendidikan dengan modelnya antara lain Pesantren Modern, Sekolah Elite Muslim, Boarding School, Madrasah Model, Madrasah Terpadu, Full Day School, dan lain-lainnya.Jika pemerintah merasa perlu atas model pendidikan itu, maka harus melakukan terobosan dan intervensi serta memposisikan diri sebagai partnership. 